\title{
Når man har sig selv med på arbejde - identitetsarbejde i en organisatorisk kontekst
}

\author{
Didde Maria Humle \& Anne Reff Pedersen
}

I artiklen stiller vi skarpt på det følelsesmæssigt krævende identitetsarbejde, der er forbundet med at performe succes og fiasko i konsulentarbejde. Konsulentfortællinger om fiasko er ofte følelsesmæssigt krævende og fragmenterede fortællinger om det personligt utilfredsstillende i ikke at kunne udføre arbejdet tilfredsstillende. Succesfortællingerne handler derimod om det meningsfulde og tilfredsstilende i gennem arbejdet at gøre en reel forskel for andre mennesker. Den meningsskabelse, der er knyttet til succes og fiaskofortællinger, er helt central for konsulenters arbejdsforståelse og deres opfattelse af overensstemmelse mellem selvdefinition og arbejdssituation. Men fortællingerne skabes ofte 'backstage', og får derfor aldrig den opmærksomhed i virksomhedens sociale liv, som kunne bidrage til en bedre forståelse af medarbejdernes følelsesliv og arbejdsliv.

" (...) det at kunne give kandidaten et drømmejob og kunden en drømmekandidat. Det er meget dejligt, når det lykkes, så har man gjort sit arbejde godt. Det er loekkert at gøre alle glade, jeg bliver også glad" (konsulent).

"Det, der kommer bag på mig, er, hvor meget det toerer at have med mange mennesker at gøre i løbet af dagen, hvordan det kan traette en, hvor benhårdt arbejde det egentlig er (...) Jeg bliver troet, det har givet sig udslag $i$, at jeg har voeret troet, når jeg kom hjem. Og det er gået ud over min familie. Det har voeret på den måde, det har voeret hårdt for mig. Der tror jeg, at denne her jobtype gør, at jeg bruger meget energi på det" (konsulent).

Tisse år er der både forskningsmæssigt 1 og i den offentlige og politiske debat stor fokus på ændringer i relationen mellem individ, arbejde og organisation i det senmoderne arbejdsliv. En af de tendenser, der ofte fremhæves i denne sammenhæng, er en opblødning af grænsen mellem det, der er arbejde og det, der ikke er arbejde. For flere og flere af os er arbejdet i dag ikke længere defineret og afgrænset ved tid og sted, hvilket potentielt gør det vanskeligere at afgrænse arbejdets omfang både tidsmæssigt og mentalt. En række danske forskere er i disse år interesserede $\mathrm{i}$ at se nærmere på betydningen af f.eks. vidensarbejderes særlige arbejdssituation i relation til temaer som overidentifikation, stress og forholdet mellem arbejde og ikke arbejde (se f.eks. Kristensen 2010; Pedersen 2008; Sørensen m.fl. 2007; Ipsen 2006). Denne forskning viser blandt andet, hvordan vidensarbejdets særlige karakteristika, høj grad af frihed, mulighed for personlig og faglig udvikling, fleksibilitet og immaterielle form, ikke, som tidligere antaget, nødvendigvis mindsker stress i arbejdet. Forskningen viser ligeledes, at grænsen mellem arbejde og 
ikke arbejde - både den tidsmæssige og den mentale i det senmoderne arbejdsliv i høj grad er blevet et individuelt problem, som først får ledelsesmæssig eller organisatorisk bevågenhed, når det er for sent - dvs. når frihed, engagement og fleksibilitet er blevet til udbrændthed og stress.

Formålet med denne artikel er at bidrage til en nuanceret, dynamisk og empirisk funderet forståelse af betydningen af en type arbejde, som udover personlig frihed, fleksibelt, udvikling og immaterialitet er kendetegnet ved en tæt kontakt til mange forskellige mennesker, og som fordrer personligt engagement og følelsesmæssig involvering.

Ovenstående citater stammer fra interview med konsulenter, hvis arbejde er kendetegnet ved, at de ved deres personlige indsats og viden gør en forskel for kunder, kandidater og samarbejdspartnere. Her er det ikke kun de faglige kompetencer, men også de mere personlige, som f.eks. intuition og empati, der er i spil. De bruger dem selv som redskab, og det personlige engagement fremstår som en vigtig forudsætning for udførelsen af arbejdet. Noget af det, der i denne sammenhæng fremstår særlig centralt, er den kendsgerning, at såvel in- som output for arbejdet er immaterielt (Ipsen 2006). Som en af de interviewede konsulenter i undersøgelsen på et tidspunkt udtrykker det: "Nogle gange ville det voere lettere, hvis man kunne sige: 'I dag har jeg produceret 10 fladskoerme og gjort et godt stykke arbejde'". Output for konsulentarbejdet er relateret til andre mennesker og vedrører f.eks. glæde og udvikling - parametre som er svære at måle på, hvilket gør det vanskeligt at vide, hvornår arbejdet er udført godt eller tilfredsstillende. Dertil kommer, at input for arbejdet stort set udelukkende består af konsulenternes personlige indsats, engagement og viden - hvilket betyder, at såvel succes som fiasko meget let bliver personlig og følelsesmæssig.
I analysen i denne artikel er der fokus på konsulenters arbejdspraksisnære fortællinger om succes og fiasko. Disse fortællinger er ofte uforgængelige og svære fortællinger, som andre medarbejdere og ledere ikke nødvendigvis har adgang til eller ved, hvordan de skal håndtere. Derfor bliver de ofte individuelle, 'backstage' fortællinger, som ikke danner ramme for en synlig medarbejderudvikling i organisationerne. Første skridt er at gøre disse fortællinger synlige og udfolde dem og dermed vise, hvordan der ligger et stort følelsesladet identitetsarbejde i at fortælle sig selv i relation til det daglige arbejde.

Først og fremmest stiller vi i artiklen skarpt på det følelsesmæssigt krævende identitetsarbejde, der er forbundet med at performe succes og fiasko i relation til konsulenters daglige arbejde. Efterfølgende vil der være en diskussion af de arbejdslivsmæssige implikationer for relationen mellem selv, arbejde og organisation samt for den ledelsesmæssige udfordring, der er relateret til at håndtere medarbejdernes arbejde med at skabe mening og identitet i relation til deres daglige arbejde.

I artiklen besvarer vi således to overordnede spørgsmål:

1. Hvilke succes- og fiaskofortællinger fremkommer i konsulenters identitetsarbejde i relation til det daglige arbejde?

2. Hvad er de arbejdslivsmæssige implikationer af analysen for relationen mellem selv, arbejde og organisation samt for den ledelsesmæssige udfordring?

Det første spørgsmål er et forskningsspørgsmål, som besvares ved en analyse af succes og fiaskofortællinger. Spørgsmål to besvares ved en kritisk og refleksiv diskussion.

De analyser, der præsenteres i denne artikel ligger i forlængelse af den del af den 
narrative organisationsforskning, som fokuserer på den diskursive og narrative konstruktion af individuel og kollektiv identitet (Mishler 1999; Humphreys \& Brown 2002; Svenningsen \& Alvesson (2003)). Der er fokus på det refleksive og dynamiske aspekt frem for de tidligere identitetsstudier, der har haft en tendens til at operere med en meget statisk opfattelse af den personlige identitet (Albert \& Whetten 1985).

Det empiriske materiale er fremkommet ved en kombination af etnografiske observationer og narrative interview. Feltarbejdet er foretaget over en periode på knap to år fra januar 2008 til oktober 2009. Konkret er der foretaget ca. 30 formelle semi-strukturerede narrative interview med medarbejdere i case virksomheden, som er et konsulentfirma med ca. 130 ansatte og kontorer i hele Danmark. I denne artikel er der fokus på to typer af konsulenter. 1: Personalekonsulenter, som arbejder med at rekruttere medarbejdere til faste stillinger og vikariater samt med relaterede HR-konsulentydelser som f.eks. genplacering af opsagte medarbejdere eller kurser i interviewteknik og 2: Jobkonsulenter, som arbejder i den del af virksomheden, der løser anden aktøropgaver (forløb for ledige) for kommunernes jobcentre over hele landet. Derudover er analysen baseret på etnografiske studier af livet i organisationen, herunder en lang række uformelle interview/samtaler og observationer samt en stor mængde dokumentation (primært kommunikation via mail og intranet).

Artiklen falder i fire dele. Efter indledningen præsenteres artiklens primære teoretiske/analytiske begreber herunder: Identitetskonstruktion, identitetsarbejde, den diskursive konstruktion af succes og fiasko samt de narrative begreber: plot, karakteristika, begivenheder, tid og diskursive strategier. Artiklens anden del er analysen og efter denne følger en kritisk diskussion af de arbejdslivsmæssige implikationer.

\section{Identitet via en diskursiv og narrativ tilgang}

Der er mange måder at forstå det følelseskrævende identitetsarbejde på. I arbejdslivsforskningen har man f.eks. undersøgt stressforhold (Siegrist 1986; Ipsen 2006; Sørensen m.fl. 2007), der f.eks. kan komme til udtryk i 'burn outs' (Maslach, Schaufeli \& Leiter 2001). Burn outs kan defineres via tre forhold: udbrændthed, distance og ineffektivitet (Maslach, Schaufeli \& Leiter 2001, 403), der har stor betydning for, hvordan arbejde kan forårsage svære og negative følelser. Følelser er et centralt begreb for at forstå identitetsarbejdet i organisationer, bl.a. har Finemann (1996a, 1996b) undersøgt forskellige følelsesarenaer; at have frygt, at være nostalgisk, at føle skyld og at være stolt som sociale konstruktioner i organisationer. Gabriel (2000) har videreført dette arbejde, bl.a. i en narrativ kontekst, hvor han har undersøgt, hvordan ansatte typiske kobler nostalgi til fortiden, som omhandler 'de gode gamle dage' i forhold til det hårde liv i organisationen i dag. I denne artikel tager vi udgangspunkt $i$, at følelsesarbejdet blandt andet sker via succes og fiasko fortællinger, som skaber den individuelle, kollektive og organisatoriske identitet.

Der opereres i denne artikel med en processuel tilgang til at forstå livet i organisationer (se f.eks. Humphreys \& Brown 2002). Organisationer opfattes ikke som homogene og lukkede enheder med en fast og definerbar organisationsidentitet. Den organisatoriske selvforståelse er i den daglige handlen og dialog under konstant (re)konstruktion. (Hazen 1993; Humphreys \& Brown 2002).

På samme måde ses den individuelle identitet i denne artikel ikke som en fast identificerbar kerne i det enkelte individ. Der er her fokus på det socialt konstruerede, narrative, dynamiske, relationelle/sociale og performative aspekt af identitet (se f.eks. Mishler 1999; White 2002; Boje 1991). In- 
spireret af Mishler (1999) anskues identitet som narrative konstruktioner, dvs. som noget, der er konstitueret i fortællinger om, hvem vi er, og hvem vi gerne vil være. Med disse fortællinger skaber vi sammenhæng og mening i det, vi gør, oplever og har oplevet. Det dynamiske aspekt refererer til en opfattelse af identitet som noget, der er foranderligt. Vi fortæller og genfortæller hele tiden os selv (individuelt, som gruppe og som organisation). Der er ikke tale om en kontinuerlig og fremadrettet identitetsudviklingsproces, som resulterer i én færdigudviklet identitet. Det relationelle eller sociale aspekt refererer til, at identitet ikke er en fast kerne, der 'bor' i den enkelte, identitet konstrueres i forholdet til og i samspillet med andre. Heraf det performative aspekt af identitetskonstruktionen, som refererer til, at vi hele tiden er i gang med at performe vores identitet i vores daglige ageren og i fortællinger. Selvfortællinger ses som kontekstbestemte identitetspræstationer. På denne måde bliver identitetskonstruktionen en evigt igangværende proces, hvor vi hele tiden tilpasser og regulerer vores identitets- eller selvfortællinger, så de giver mening for os selv og andre. En proces som blandt andet finder sted i en organisatorisk kontekst i relation til arbejde.

\section{Identitetsarbejde}

En måde at konceptualisere identitet i processuelle termer, i en organisatorisk kontekst, er via Svenningsen og Alvessons (2003) begreb identitetsarbejde. Med denne term fremhæves de dynamiske aspekter og den 'on-going struggle' omkring det at skabe en følelse af selv og frembringe midlertidige svar på spørgsmålet om: "Hvem er jeg (vi)?" og "Hvad står jeg (vi) for?". Identitetsarbejde er det arbejde eller den 'kamp', vi mennesker er involveret i/optaget af, når vi konstant er i gang med at forme, reparere, vedligeholde, styrke eller revurdere de kon- struktioner, som er produktive i relation til en følelse af sammenhæng og særegenhed.

I den organisatoriske kontekst stræber vi som individer, ifølge Svenningsen og Alvesson (2003), efter komfort, mening og integration (samhørighedsfølelse) samt efter en form for overensstemmelse mellem en selvdefinition og en arbejdssituation. Organisatoriske diskurser, rolleforventninger og narrative selvidentiteter er alle en del af dette identitetsarbejde eller denne kamp.

En måde at udforske identitetsarbejdet på er via praksisnære fortællinger om arbejde, fremover kaldet arbejdspraksisfortoellinger. Det er f.eks. fortællinger om en interessant arbejdsopgave, en god arbejdsdag, en mindre interessant arbejdsopgave, en situation, hvor personen følte, at han/hun gjorde sit arbejde godt eller mindre godt osv. De arbejdspraksisfortællinger, som er genstand for analyse i denne artikel, anses for at være stemmer i den polyfoniske (mangestemmede) organisation (Hazen 1993). De er del af de konstante meningsskabelsesprocesser, hvorved organisationsmedlemmerne formulerer og reformulerer såvel individuelle som organisatoriske selvopfattelser. Den historiefortælling, som finder sted i interviewsituationen, opfattes således som en præstation og fortællingerne som identitetsarbejde eller identitetspræstationer.

\section{Succes og fiasko i arbejdspraksisfortællinger}

Særligt arbejdspraksisfortællinger om succes og fiasko viser konsulenternes identitetsarbejde, da de fremhæver de følelsesladede aspekter af identitetskonstruktionerne. Arbejdspraksisfortællinger om succes og fiasko analyseres i denne artikel via seks analytiske begreber: Plot, karakteristika, begivenheder, tid og diskursive strategier.

Et plot refererer til et fokus på, hvad det er, der kæder begivenhederne sammen til en meningsfuld helhed (Renemark 2007). 
Arbejdspraksisfortællingerne opdeles i første omgang efter deres indbyrdes indholdsmæssige sammenhæng.

Karakteristika refererer til de fællestræk, der karakteriserer fortællingerne inden for de forskellige overordnede plot. Herunder om det er fortællinger med særlige kendetegn som f.eks. udvikling, fremdrift og harmoni eller tragiske fortællinger om meningsløshed og stagnation.

Begivenhederne er de hændelser, der sker i fortællingen. Fortællingerne kan være berettelser om konkrete hændelser, men også habituelle begivenheder (begivenheder der sker igen og igen uden kulmination), hypotetiske begivenheder samt tematisk-centrerede begivenheder (hvor episoder af hændelser er tematisk forbundne). Sådanne fortællinger har ikke nødvendigvis en begyndelse, en kulmination og en afslutning, og der er heller ikke altid fastdefinerede karakterer eller hovedpersoner (Riessman 1993).

Tid handler om, hvordan begivenhederne er koblet til hinanden. Fortællingerne kan være tidskronologiske, men også cykliske (periodiske) eller kairotic (en fortælling, hvor vigtige begivenheder fremhæves, uden hensynstagen til kronologi) (Czarniawska 2004). Et andet narrativt tidsbegreb, som anvendes i analysen, er tidsskygger (Pedersen 2009), som referer til en asymmetrisk tidsdimension. Det vil sige fortællinger, hvor fortælleren ikke altid anvender en kronologisk eller lineær tid. I denne artikel anvender vi begrebet tidsskygge, når fortælleren opererer med en hypotetisk fremtid. Når fremtiden allerede er fortalt, bliver nutiden en forberedelse til denne hypotetiske fremtid. 'Sideskygger' er defineret ved, at fortælleren i sin fortælling har fokus på de muligheder, der kunne have været, hvis tingene havde været anderledes. Denne hypotetiske nutid har betydning for, hvordan tingenes 'faktiske' tilstand opfattes og for den mening, som begivenheder og handlinger tilskrives.
Begge typer af tidsskygger har betydning for fortællerens meningsskabelse og opfattede handlemuligheder (Pedersen 2009).

Fortællingerne skabes i relation til en række fælles diskursive forestillinger eller rammer, som i analysen i denne artikel primært relateres til den organisatoriske kontekst; konsulentfirmaet. Begrebet diskursiv ramme anvendes med inspiration fra Vaares (2002) studie af succes- og fiaskofortællinger i relation til fusioner. Vaare identificerer forskellige diskursive rammer, som de interviewede benytter, når de retrospektivt fortæller om deres oplevelse af fusionen. Diskurserne udgør en ramme for fortællingerne og samtidig begrænser de måden, hvorpå de kan konstrueres. Knyttet til de diskursive rammer er specifikke diskursive strategier, som fortælleren benytter i håndteringen af det pres, der er forbundet med at håndtere succes og fiasko.

I Vaares studie bruger de interviewede fortællingerne til at retfærdiggøre og legitimere deres egne handlinger i konteksten. I succesfortællinger er der en tendens til, at de interviewede lægger vægt på deres egen rolle og betydning for succesen f.eks. ved at pege på egne eller gruppens handlinger. I fiaskofortællingerne er der to primære diskursive strategier eller 'moves', som fortællerne benytter for at håndtere fiaskoen og undgå at attribuere fiasko til egen formåen. Den første er at fokusere på en 'rollebestemt' diskurs, hvor selv de mest magtfulde aktører kan portrætteres som magtesløse. Den anden strategi er at attribuere ansvaret for fiaskoen til andre aktører eller omstændighederne. De diskursive strategier er ifølge Vaare (2002) en måde, hvorved fortælleren forsøger at håndtere det komplekse sociopsykologiske pres, der er associeret med at håndtere succes/fiasko.

Ved at analysere konsulenternes arbejdspraksisfortællinger via plot, tid, karakteristika, begivenheder, diskursive rammer og 
diskursive strategier er det muligt at vise, hvordan konsulenternes identitetsarbejde skabes dels via narrative rammer, der rummer dramaturgiske og emotionelle betingelser, dels via meningsgivende diskursive rammer, der viser, at det at skabe mening med sit arbejde ikke blot kommer af sig selv, men er hårdt arbejde, der ofte udfoldes i tavse og individuelle fortællinger om succes og fiasko i hverdagen.

\section{Analyse: Fortællinger om succes og fiasko i konsulentarbejde}

Analysen i denne artikel er en delanalyse af empirien fra et treårigt ph.d. projekt. Det empiriske materiale er baseret på etnografiske observationer og narrative interview. Sidstnævnte er foretaget via en dialog og uden tematisk fast interviewguide, men med processuel, metodisk guide (Czarniawska 2004). Analysen er en tematisk narrativ analyse med fokus på forskelle og forskellige temaer på tværs af interviewene og det øvrige empiriske materiale (Riessman 2008). De citater, der anvendes i analysen, er repræsentative citater fra analysen af de 30 interview, dvs. at de repræsenterer temaets flertal.

Analysen falder i tre dele. Første og anden del er et opsummerende uddrag af afhandlingens analyse af henholdsvis succes- og fiaskofortællinger. Tredje del er en kort opsummering af analysens vigtigste konklusioner og pointer, som skal lede op til en afsluttende diskussion af de arbejdslivsmæssige implikationer for relationen mellem selv, arbejde og organisation og for den ledelsesmæssige udfordring.

\section{Den narrative og diskursive konstruktion af succes}

Konsulenternes arbejdspraksisfortællinger om succes handler ofte om udfordringer og fremdrift. Det er f.eks. fortællinger om at gøre det rigtige, gøre et godt stykke arbejde, handle i overensstemmelse med virksomhedens værdier, skabe glæde, løse det uløselige via den ekstraordinære indsats eller skabe fremdrift for andre mennesker. Analysen viser, at de mange succesfortællinger falder i to overordnede plottyper:

1. Type A: Fortællinger om, hvordan man via denne type arbejde med en personlig indsats og engagement har mulighed for at skabe reel værdi, fremdrift og glæde for andre mennesker (kandidater, kunder, samarbejdspartnere og kollegaer).

2. Type B: Fortællinger om den vanskelige opgave eller situation, der via en ekstraordinær indsats fra konsulenten og dennes kollegaer ender med at blive løst tilfredsstillende.

\section{Succesfortællinger type A: Om at skabe} værdi, fremdrift og glæde for andre

Denne type af fortællinger er der rigtigt mange af i det empiriske materiale både fra interview og fra de på intranettet distribuerede succeshistorier fra hverdagen. De er kendetegnet ved en meget eksplicit reference til en overordnet diskursiv forestilling om, at denne type arbejde er meningsfuldt, når der er mulighed for at skabe reel værdi for andre mennesker.

Fortællingerne er karakteriseret ved, at de omhandler udvikling og fremdrift. Herunder primært i relation til de jobsøgende kandidater, men også i forhold til kunder, samarbejdspartnere og kollegaer. Her fremhæves både den 'store', ekstraordinære eller overraskende udvikling og de små forandringer eller små skridt på vejen mod et arbejde, personlig afklaring eller et bedre liv. Fortællingerne kan være beskrivelser af habituelle (sker igen og igen), hypotetiske eller tematisk-centrerede begivenheder: 
"Hvis jeg kan finde ud af at flytte folk personligt eller fagligt blot ved at saette mig ned og stille de rigtige spørgsmål, så synes jeg sgu, jeg er dygtig. Så er der ikke meget andet, der giver mig større succes" (konsulent).

Succesfortællinger om værdi, fremdrift og glæde henviser ofte til konkrete personer, hændelsesforløb eller begivenheder:

Interviewer: "Kan du beskrive en situation, hvor du følte, at du giorde dit arbejde rigtigt godt?"

Konsulent: "Ja, det kan jeg godt [latter] jeg havde en episode, med en langtidsledig, som kom og sagde, at hun gerne ville ind til samtale. Hun fortalte, at hun havde voeret ledig $i$ ti år, og jeg toenkte: 'Hold da op, hvordan fär jeg dig ud'. Men hun kom ind til en samtale, og det var rigtig, rigtig hyggeligt, hun var meget udadvendt og lidt en soelger type, og hun havde egentlig ikke voeret ledig hele tiden, fordi hun havde i mellemtiden taget en uddannelse. Hun havde haft noget depression, men nu var hun kommet oven på igen, og ville gerne have en chance, men hun kunne bare ikke få noget, fordi hun har voeret ledig $i$ de sidste mange år. Vi havde en rigtig god samtale, og så går jeg ud til min kollega og siger: 'Jeg har en rigtig god kandidat, og nu vil jeg bare prøve at se, om jeg ikke kan finde noget til hende'. Og så siger han: 'Jeg har lige modtaget en ordre, jeg skal bruge en receptionist om en times tid' og så toenkte jeg nå [latter] 'jeg går lige tilbage igen og spørger, om det er noget, hun har lyst til', og hun sagde: 'Det vil jeg gerne'. Det var et sted ude på bøhlandet, og så sagde jeg til hende: 'hvis du lige tager en kop kaffe, så kommer jeg tilbage om lidt', og jeg havde lige sagt til hende, at jeg desvoerre ikke havde noget lige $n u$. Hun var rimelig proesentabel $i$ tøjet, så det var jo bare perfekt, når hun skulle ud $i$ en reception. Kunden havde lagt ordren, og min kollega havde sagt, 'Jamen det er ikke realistisk, at vi kan løse den om en time', og så kom jeg tilbage fra samtale. Det var en uges vikariat, og bagefter blev hun forloenget. Min kollega blev glad, ligeså kunden og det samme med saelgeren og selvfølgelig blev jeg glad, fordi hun kom ud, og hun blev også glad, og plus vores samarbejdspartnere [Akassen] blev også glade, så det var en rigtig loekker oplevelse, så gik der et stykke tid, og så siger en kollega: 'Jeg har brug for en receptionist til en fast stilling', og der blev hun så rekrutteret. Det sker ikke så tit at tingene passer så godt sammen, men det er bare en god fornemmelse, når det sker."

I det sidste citat fortæller konsulenten historien kronologisk fra begyndelse til slutning uden afbrydelse. Som afrunding benyttes en form for evalueringsklausul (Riesmann 1993), dvs. at konsulenten fortæller, hvordan historien skal tolkes eller hvilken betydning, den har for hende. Hun slår fast, at dette er en 'succes' historie, fordi det endte godt, og alle var glade. Konsulenten fortæller her sig selv som en person for hvem, det har betydning, at hun gennem sit arbejde opnår succes ved at gøre alle glade. Der er i det empiriske materiale mange konkrete og kronologisk fortalte fortællinger om situationer, hvor konsulenten alene eller i samarbejde med andre har haft mulighed for at gøre en forskel for andre mennesker. Det er ofte fortællinger om mennesker, som af den ene eller anden grund er havnet $i$ en svær situation, men som i mødet med konsulenten får mulighed for en ny chance:

"Sådan en historie. En mand, der ligner døden fra Lübeck og nu er frisk og glad for sit arbejde, det er fantastisk, det boerer lønnen $i$ sig selv" (konsulent).

Konsulentens rolle sidestilles som i fortællingen om den langtidsledige kvinde ofte med andres indsats eller heldige sammen- 
fald af muligheder. Fortællingerne fremskriver en overensstemmelse mellem selvdefinition og arbejdssituationen, og det er relativt ukompliceret for konsulenterne at fortælle sammenhængende og meningsfulde historier om selv og arbejde med den pågældende virksomhed som organisatorisk kontekst.

Succesfortælling type B: Om den vanskelige opgave og den ekstraordinære indsats

Denne type fortællinger handler ofte om de vanskeligheder, der kan være forbundet med udførelsen af arbejdet, og om hvordan konsulenter via den ekstraordinære indsats og det personlige engagement har mulighed for at overkomme forhindringer og skabe succes. Fortællinger af denne type er kendetegnet ved en direkte reference til en diskursiv forestilling om, at arbejdet er meningsfuldt, når det giver mulighed for at skabe en reel værdi for andre mennesker.

Fortællingerne er igen karakteriseret ved et fokus på udvikling og fremdrift samt ved den glæde, der er forbundet med at løse den svære udfordring. Mange af fortællingerne refererer til konkrete begivenheder og hændelsesforløb, og de er ofte fortalt med udgangspunkt i en kronologisk tidsramme:

Interviewer: Kan du fortoelle om en situation, hvor du følte, at du gjorte dit arbejde rigtigt godt?

Konsulent: Det burde ikke voere svoert. Det gør jeg hver dag [latter]. Jeg havde en kandidat, som jeg vidste, var misbruger. Jeg havde problemer med at få fat $i$ ham, men havde god kontakt med ham, når han var her. Jeg toenkte, det skal ikke vaere ufors $\emptyset g t$, så jeg tog simpelthen et brev, jeg havde skrevet til ham og tog hjem til ham. Han boede i stuen, og jeg vidste, at han havde en hund. Jeg kunne se, at han var der, men han lukkede ikke op. Jeg sagde gennem døren, at det var mig, og at jeg kom for at aflevere et brev, og ville putte det ind under døren. Postkassen var brudt op. 'Jeg er her kun, fordi jeg vil hjoelpe dig, og jeg synes, du skal komme ud af busken, fordi det er den eneste måde, vi kan hjoelpe dig, så du kan komme videre, det er, hvis du kommer frem, ellers kommer du ingen vegne'. En stemme indefra sagde: 'Tak, fordi du kom Lene [fiktivt navn], jeg skal nok ringe i morgen, så vi kan få en snak, og undskyld jeg ikke har gjort det før, jeg har voeret lidt nede'. Jeg sagde 'Det er i orden, jeg gloeder mig til at høre fra dig, jeg loegger brevet her'. Og fluks ringer han noeste dag. Der toenkte jeg bare ja, det nytter, det er jo ikke noget, der hører med til jobbet. Men det er noget, der gør en forskel, at han moerker den der rigtige oprigtige interesse i ham som menneske. Han ringede, og vi blev enige om, at han skulle gå hos min kollega for at få noget mere afklaring, og jeg toenkte, ja det nytter noget, jeg synes, det var aergerligt at give op, fordi den mand havde nogle ressourcer".

I ovenstående fortælling er konsulenten ved hjælp af den ekstraordinære menneskelige indsats i stand til at hjælpe en kandidat. Opgaven er vanskelig og sandsynligheden for succes lille. Der er i denne type fortællinger en mere direkte personificering af succesen, dvs. et større fokus på egne handlinger og betydningen af disse for det positive udfald. Det er den menneskelige og ekstraordinære indsats, der er i fokus. Der references i ovenstående citat, som i mange af de andre af denne type fortællinger til en hypotetisk og mere tragisk fremtid, hvor kandidaten ikke bliver hjulpet. Denne skyggetid har betydning for tilskrivningen af mening. Uden konsulentens personlige indsats og blik for kandidatens ressourcer er der i fortællingen en mere tragisk potentiel fremtid, og tilstedeværelsen af denne forstærker det meningsfulde i det positive udfald.

Arbejdet fremstår i denne type fortællinger som en kilde til personlig tilfredsstillelse 
og glæde. Ved det ekstraordinære menneskelige engagement har konsulenterne mulighed for gennem arbejdet med mennesker at opnå positive følelser som stolthed og glæde, men skyggetiderne vidner om den potentielle personlige fiasko som en evigt tilstedeværende mulighed.

\section{Den narrative og diskursive konstruktion af fiasko}

Fiaskofortællingerne er ofte fortællinger om situationer eller perioder, hvor det af den ene eller anden grund er vanskeligt for konsulenterne at føle, at de har mulighed for at udføre deres arbejde tilfredsstillende. Arbejdspraksisfortællinger om fiasko fra det empiriske materiale falder i to overordnede plottyper:

1. Fiaskofortælling type A: Om hvordan tidspres og ressourcemangel til tider gør det vanskeligt at opnå den ønskede kvalitet i det daglige arbejde.

2. Fiaskofortælling type B: Om følelser af personlig utilstrækkelighed i relation til det daglige arbejde.

Fiaskofortælling type A: Om tidspres og manglende kvalitet $\mathrm{i}$ arbejdet

Denne type af arbejdspraksisfortællinger om fiasko er karakteriseret ved, at de ofte er 'tragiske' fortællinger om det utilfredsstillende i at føle sig ude af stand til at gøre et godt stykke arbejde, og de fremstår krævende for konsulenternes identitetsarbejde med at skabe mening og sammenhæng mellem forestillinger om selv, arbejde og organisation.

De er ofte bygget op omkring et tematiskcentreret underplot som f.eks. 'manglende tid' og/eller 'manglende kvalitet'. Begivenhederne kan godt være faktiske hændelser, men oftere er de fiktive eller hypotetiske.
Der er en del af fortællingerne, hvor begivenhederne er habituelle, det vil sige, hvor det er uspecificerede hændelser, som er typiske eller almindelige i den forstand, at de forekommer mere end en gang:

"Det er, når det høvler ind med ansøgninger. Så får jeg dårlig samvittighed over at gå hjem. Vi er også blevet mere ufleksible, fordi vi er foerre. Så kan vi ikke altid leve op til den høje standard og kvaliteten daler. Vi kan ikke svare hurtigt til alle kandidater. Der er hele tiden et konstant pres, og det fremmer ikke kvaliteten. Jeg ringer altid tilbage til kandidaterne. Det er vigtigt for mig at leve op til kvalitet og etik. Folk skal behandles ordentligt, men jeg kan desvoerre ikke altid leve op til det. (...) Det er f.eks., hvis vi ikke kan nå ud til en kunde før, der sendes vikarer derud. Så kan jeg kun garantere for det faglige, uden at vide om personen passer ind. Det er på ingen måde tilfredsstillende. Det er ikke sjovt, fordi hvis jeg skal gøre mit arbejde godt nok, så skal jeg ud og sige hej til kunden, om det så bare er 20 min" (konsulent).

"Der mangler folk, og så ville det godt kunne blive godt, hvis vi var flere. Så ville der voere tid til at få dem [kandidaterne] ud. Jeg har ikke tid til at formidle kandidaterne. Det er som om, vi skal først skal broende ud (...) vi siger det hver dag, og det har vi giort i flere måneder, men der kommer ikke nogen, det er ved at blive for meget nu" (konsulent).

Der er specielt i det sidste citat en tydelig skyggetid, som her er defineret ved, at fortælleren har fokus på de muligheder, der kunne have været, hvis tingene havde været anderledes. Konsulenten giver udtryk for, at kvaliteten i arbejdet kunne være bedre, hvis der var flere ressourcer og mere tid. Den hypotetiske nutid får sammen med konsulentens ønske om at udføre kvalitet betydning for, hvordan tingenes 'faktiske' 
tilstand opfattes. Ledelsen får her som i mange andre lignende fiasko fortællinger, det overordnede ansvar for den manglende kvalitet, og det er således vanskeligt at fortælle meningsfulde og sammenhængende fortællinger om selv, arbejde og organisation. Samtidig har skyggetiden betydning for fortællerens meningsskabelse og opfattede handlemuligheder. Underplottet 'manglende tid' forhindrer konsulenterne $i$ at 'handle' sig til bedre resultater.

I begge citater er der implicit reference til den diskursive forestilling om det meningsfulde i at skabe reel værdi for andre. Arbejdet mister pga. tidsmangel og manglende mulighed for kvalitet noget af sin mening. Her afspejles den organisatoriske dialog, der handler om at definere, hvad kvalitet er, eller hvad det vil sige at udføre arbejdet tilfredsstillende. Eksemplerne illustrerer, hvordan kvalitet oftest er mest synlig i relation til de situationer, hvor kvaliteten 'halter', eller hvor arbejdet ikke lever op til en individuel eller kollektiv opfattelse af, hvad kvalitet er. Når omstændighederne, her tidspres og manglende ressourcer, gør det vanskeligt at opnå den ønskede kvalitet i det meningsfulde arbejde med kandidater og kunder, bliver fortællingerne ofte mere alvorlige, fragmenterede og usammenhængende.

Formuleringer som "Så får jeg dårlig samvittighed over at gå hjem" og "Jeg har ikke tid til at formidle kandidaterne" indikerer, at fiaskoen bliver meget personlig og følelsesladet, og at den får betydning for opfattelse af sammenhæn mellem selvdefinition og arbejdssituation. Der er en distribuering af ansvar til årsager, der ikke har med konsulentens handlinger at gøre. Specielt i det sidste citat er der en tydelig distribuering af ansvar til ledelsen, som efter konsulentens mening ikke tager behovet for flere ressourcer alvorligt.

For at håndtere den eller de åbenlyst utilfredsstillende situation(er) anvender kon- sulenterne forskellige diskursive eller narrative strategier, f.eks. en 'kraftig' insisteren på kvalitet i arbejdet og på, at tingene skal gøres på en etisk forsvarlig måde. Ved at fremhæve et personligt ' $\mathrm{krav}^{\prime}$ om kvalitet i arbejdet fraskriver konsulenten sig ansvaret for den manglende kvalitet. Konsulenterne ønsker kvalitet og er villige til at yde en ekstraordinær indsats for skabe den, og herved er fokus eller ansvar forflyttet til de urimelige betingelser opstillet af branche, organisation eller ledelse.

Fiaskofortælling type B: Om følelsen af personlig utilstrækkelighed

Disse fortællinger er karakteriseret ved at være tragiske fortællinger med reference til en rollebundet diskurs (Vaare 2002), hvor konsulenterne pga. omstændighederne for arbejdet fremstår som aktører uden reelle handlemuligheder. Kendetegnende for fortællingerne er et fokus på følelsen af personlig utilstrækkelighed:

"I denne her specialistrolle, der bliver jeg tit stillet $i$ en situation, hvor jeg skal definere nogle stillinger, som jeg ikke har ret meget forstand $p a ̊$, og der føler jeg mig tit utilstraekkelig. Argumentationen er selvfølgelig, at jeg er mere kompetent end en kollega, der har en helt anden type uddannelse. Men i forhold til mig selv, der føler jeg tit i de situationer, at der slår jeg ikke til. Det er jo det, vi bliver solgt på, og jeg er også blevet solgt på, jamen Trine [fiktivt navn] kommer, og hun har helt styr på, hvad det er, I laver, og jeg kommer bare ud og har ikke en hak forstand på, hvad det er, de laver. Jeg kan da godt se, at det er sådan nogle maskiner, men nå ja, jeg ved da ikke, hvordan de fungerer, og det er sådan ligesom at skulle lade lidt som om, at skulle lade lidt som om, at det har jeg lidt styr på, $i$ hvert fald til en vis graense, og det har jeg egentlig ikke. Der sidder jeg tit i nogle 
situationer, hvor jeg ikke synes, at jeg kan udfylde min rolle godt nok (...) Det gør mig usikker, og det gør også, at jeg synes, det er traels. Det er det her med, at jeg gerne vil gøre det $100 \%$, og det synes jeg ikke, at jeg kan $i$ de tilfoelde, og det er nok også det, jeg har haft svoert ved at vende mig til, at det er faktisk godt nok, det jeg gør. Det kan godt voere, jeg ikke forstår proecis, hvad det er de laver, men du er med et godt stykke hen ad vejen, og så er det fint" (konsulent).

"Der var en kandidat, der ikke ville kommunikere, og jeg var bekymret for, om han ville blive voldelig. Min kollega havde sendt ham hjem. Jeg vidste ikke, hvad jeg skulle gøre og følte ikke, at jeg havde kompetencerne til det. Der var også en kandidat, der var psykisk syg. Han fortalte, at han havde voeret udsat for sort magi siden, han var lille. Han troede, han havde dyr i kroppen, og at han fik elektrisk stød om natten. Jeg vidste ikke, hvad jeg skulle gøre for ham. Det har jeg slet ikke kompetencer til at håndtere. Jeg prøvede om jeg kunne grine lidt af det. Men hvis der er for mange af sådanne situationer, så kommer jeg til at troekke mig tilbage og pege på mig selv. Og spørge mig selv, 'hvorfor kan jeg ikke håndtere sådan en mand, hvor han skal henvende sig'" (konsulent).

Plottet er i de to eksempler, som det ofte er tilfældet i denne type fortællinger, en følelse af personlig utilstrækkelighed i relation til elementer af det daglige arbejde. Begge fortællinger er centreret omkring samme tema; manglende mulighed for at udføre arbejdet tilfredsstillende pga. manglende kompetencer. I det sidste citat er fortællingen konstrueret med udgangspunkt i den overordnede diskursive forestilling om, at det, der gør denne type arbejde meningsfuld, er muligheden for at skabe reel værdi for andre mennesker. Konsulenten ser sig ikke i stand til at gøre en forskel for kan- didaterne, og arbejdet fremstår derfor meningsløst. Der er i fortællingen, som i andre af denne type fortællinger en skyggetid, hvor fremtiden fremstår forudbestemt. Udvikling og fremdrift er ikke et muligt eller realistisk fremtidsscenarie, og konsulentens muligheder for at 'handle' og udføre et meningsfuldt stykke arbejde begrænses herved. Når kandidaternes fremtid på denne måde skygges af en allerede fastsat og negativ fremtid, bliver det vanskeligt at fortælle meningsfulde beretninger om fremdrift og succes, og fortællingerne fremstår som fragmenterede og vanskelige selvfortællinger.

I den retrospektive meningsskabelse bliver den primære diskursive eller narrative strategi en attribution af ansvar til omstændighederne for arbejdet herunder betingelser opsat af ledelse, organisation og branche. Selv om konsulenterne i denne type fortællinger forsøger at fordele ansvaret for fiaskoerne til eksterne faktorer, fremstår identitetsarbejdet med at opretholde den positive selvdefinition og personlige integritet som en kamp, og den opfattede relation mellem selv, arbejde og organisation fremstår problematisk og ikke meningsfuld.

\section{Opsamling}

I indledningen blev forskningsspørgsmålet stillet: "Hvilke succes- og fiaskofortællinger fremkommer i konsulenters identitetsarbejde i relation til det daglige arbejde?".

Analysen af henholdsvis succes og fiasko viser, at der er meget forskellige måder at skabe og fremvise fiasko og succes på, og at det er meget mere krævende identitetsarbejde at skabe og fremvise en fiasko. Fiaskoen tilskrives personlig utilstrækkelighed eller omstændighederne for arbejdet, og succesen i højere grad egne handlinger og den ekstraordinære personlige indsats.

I fiaskofortællingerne skabes tid ofte via en hypotetisk tid, hvor fortælleren anvender skyggetider til at forstå det, som 
er sket, ved at relatere til det, som kunne være sket. Fortællingerne har tragiske træk og fremskriver en meningsløshed, fordi der refereres til arbejdsdiskurser om kvalitet $\mathrm{i}$ arbejdet og det meningsfulde i at skabe reel værdi for andre mennesker. Hvilket i disse fortællinger ikke er muligt. I kontrast hertil står succesfortællingerne, som handler om fremdrift og glæde via den personlige indsats. Der refereres her ukompliceret til individuelle faktorer og til en diskursiv forestilling om mening $i$ arbejdet via muligheden for at skabe reel værdi for andre.

Begge disse typer af fortællinger viser, at det har stor betydning for konsulenterne, om de i relation til deres daglige arbejde skaber mening eller ikke mening ved at skabe værdi og glæde for andre mennesker. Det helt centrale forhold bliver her relationen til og mødet med andre mennesker samt muligheden for at føle sig som en succes i relation til arbejdet med kandidater og kunder.

\section{Diskussion}

I denne afsluttende diskussion vil vi diskutere det andet spørgsmål, vi stillede i indledningen: "Hvad er de arbejdslivsmæssige implikationer af analysen for relationen mellem selv, arbejde og organisation samt for den ledelsesmæssige udfordring?".

Analysen viser, hvordan det er vanskeligt for konsulenterne i denne undersøgelse at opretholde en adskillelse mellem succes og fiasko i arbejdet på den ene side og deres egen selvforståelse eller selvdefintion på den anden side. De er redskabet for deres arbejde, og der er ikke noget filter eller produkt mellem dem og resultatet af arbejdet. Både succes og fiasko bliver derfor meget let personlig. Den problemstilling sættes yderligere på spidsen af det faktum, at succes ofte frembringes ved hjælp af den ekstraordinære personlige indsats og det følelsesmæssige og menneskelige engage- ment i arbejdet. Det er i høj grad op til den enkelte konsulent at optimere egen indsats for herved at skabe succesen, og skyggetiderne vidner samtidig om, at den potentielle fiasko altid er tilstede. Succesen bliver således et personligt projekt og håndteringen af fiasko en individuel identitetskamp. Samtidig er der hos konsulenterne et udtalt ønske om at skabe kvalitet i arbejdet og reel værdi for andre mennesker. En nærliggende implikation er, som vi ser det, at det bliver vanskeligt for den enkelte konsulent at begrænse arbejdets omfang tidsmæssigt og mentalt. Dels fordi det er vanskeligt at opnå organisatorisk konsensus om, hvornår arbejdet er udført tilfredsstillende, men også fordi konsulentens investering af ekstra tid og engagement $i$ arbejdet bliver den mest nærliggende måde at optimere eller sikre kvalitet på.

I den offentlige debat fremstilles opblødningen af såvel den tidsmæssige som den mentale grænse mellem arbejde og ikke-arbejde, som mange af os oplever i det senmoderne arbejdsliv, ofte meget stereotyp og unuanceret. På den ene side er der den rosenrøde fremstilling, hvor det organisatoriske eller ledelsesmæssige krav om personligt engagement er i overensstemmelse med medarbejderens behov for personlig udvikling og mening $i$ arbejdet. På den anden side er der den meget pessimistiske fremstilling, hvor arbejdets natur og de ledelsesmæssige præferencer i højere og højere grad kræver 'det hele menneske'. Her bliver det umuligt for medarbejderen at adskille arbejde og ikke-arbejde, og i yderste konsekvens presses medarbejderen til en tilstand af overidentifikation, udbrændthed og stress. Det empiriske materiale, som ligger til grund for analyserne i denne artikel, vidner om en mere nuanceret 'virkelighed', hvor konsulenternes daglige arbejde ikke alene er følelsesmæssigt og personligt krævende og potentielt stressende, men også 
en meningsfuld kilde til personlig tilfredsstillelse og glæde.

Der er således en følelsesmæssig dobbelthed forbundet med denne type arbejde. Så længe det er muligt at udføre det daglige arbejde tilfredsstillende, fremstår arbejdet med mennesker ikke kun som en mulighed for at skabe professionel eller arbejdsmæssig succes, men ligeledes som en kilde til personlig tilfredsstillelse og glæde. Den opfattede fiasko gør det derimod vanskeligt at fortælle sammenhængende og meningsfulde fortællinger om selv, arbejde og den organisatoriske kontekst. Analysen viser, hvordan følelsen af utilstrækkelighed i relation til det daglige arbejde ofte er forbundet med en ambivalens i relation til branche, organisation og ledelse. Fiaskoen gør derfor relationen mellem individ og branche/organisation/ledelse sårbar. Ifølge Svenningsen og Alvesson (2003) stræber vi som individer i vores identitetsarbejde i den organisatoriske kontekst efter komfort, mening og integration samt efter en form for overensstemmelse mellem en selvdefinition og en arbejdssituation. Vi vil gerne fortælle meningsfulde og sammenhængende fortællinger om os selv, vores arbejde og den virksomhed, vi arbejder i. Det ikke altid muligt, og analysen viser, hvordan muligheden for at skabe mening har betydning for vores opfattelse af arbejdet og virksomheden.

I denne type arbejde, som udover personlig frihed, fleksibilitet, udvikling og immaterialitet er kendetegnet ved en tæt kontakt til mange forskellige mennesker samt personligt engagement og følelsesmæssig involvering bliver forståelse for den enkelte medarbejders identitetsarbejde et vigtigt element i ledelsesarbejdet. Der er her nogle helt centrale ledelsesmæssige udfordringer, som vi mener, det er væsentligt at fremhæve. Det sætter fokus på det ledelsesmæssige ansvar i forhold til sikre, at det personlige engagement og den følelsesmæssige invol- vering i arbejdet ikke medfører overengagement og grænseløshed samt i yderste konsekvens udbrændthed og stress.

I analysen viser vi, hvordan det ikke-tilfredsstillende arbejde ofte kædes sammen med manglende kvalitet i arbejdet som en konsekvens af tids- og ressourcemangel. Her er det relevant at fremhæve det ledelsesmæssige ansvar for jerntrekanten (Atkinson 1999), som består af tre hjørner: opgavekvalitet, ressourcer og tid. Ideelt skal der være balance imellem disse tre, således at der er tid og ressourcer nok til at skabe kvalitet $\mathrm{i}$ arbejdet, men det er ikke altid tilfældet. Analysen i denne artikel viser, hvordan konsulenterne ikke altid føler, at ledelsen påtager sig et ansvar for at opretholde eller skabe balance mellem tid, ressourcer og opgavekvalitet. Både ledelse og medarbejdere deler en fælles diskursiv forestilling om, at kvalitet i relation til det daglige arbejde er vigtig, men der er ikke en konsensuspræget forståelse af, hvordan kvalitet ser ud i praksis. Det bliver således i høj grad op til den enkelte medarbejder at definere, hvad kvalitet er, og samtidig er det et individuelt ansvar at håndtere den manglende kvalitet.

Som en konsekvens heraf mener vi, at ledere bør tage betydningen af succes og fiasko i relation til det daglige arbejde alvorligt og så vidt muligt understøtte medarbejdernes muligheder for at skabe og fremvise succes $i$ arbejdet. Samtidig er der en vigtig ledelsesmæssig udfordring med at håndtere medarbejdernes identitetsarbejde i relation til fiaskoen - som altid vil udgøre en potentiel del af arbejdet. Det er en ledelsesmæssig udfordring at kunne bruge medarbejdernes arbejdspraksisfortællinger ikke mindst, fordi det identitetsarbejde, der er forbundet med at skabe mening omkring succes og fiasko, ofte foregår 'backstage'. Det kræver, at ledelsen bliver åbne overfor disse tavse og individuelle fortællinger og f.eks. aktivt deltager i at understøtte konstruktionen af 
fiaskofortællinger som en naturlig del af ledelsesarbejdet. Det handler således ikke om at undgå fiaskofortællinger, men om at understøtte konsulenterne $\mathrm{i}$ det hårde narrative arbejde med at skabe fortællingerne og fortælle dem videre.

\section{REFERENCER}

Albert, Stuart \& David Whetten (1985): Organisational Identity, i L.L. Cummings \& B.M. Staw (red): Research in Organizational Behaviour, 7, 263-295, Greenwich, CT: JAI Press.

Atkinson, Roger (1999): Project Management: Cost, time and quality, two best guesses and a phenomenon, its time to accept other success criteria, i International Journal of Project Management, 17, 6, 337-342.

Boje, David M. (1991): The Storytelling Organization: A study of Story Performance in an Office-supply Firm, i Administrative Science Quarterly, 36,106 -126.

Czarniawska, Barbara, (2004): Narratives in Social Science Research, London, Sage.

Fineman, Stephen (1996a): Emotions and organizing, i S. Clegg, C Hardy and W. Nord (red): Handbook of organization studies, London, Sage.

Fineman, Stephen (1996b): Emotional subtext in Corporate Greening, i Organization studies, $17,3, .479-500$.

Gabriel, Yiannis (2000): Storytelling Organizations, London, Oxford.

Hazen, Mary Ann (1993): Towards Polyphonic Organization, i Journal of Organizational Change management, 6, 5, 15-26.

Humphreys, Michael \& Andrew Brown (2002): Narratives of organizational identity and identification: A case study of hegemony and resistance, i Organization Studies, 23(3), 421.

Ipsen, Christine (2006): Vidensarbejderens saerlige arbejdssituation og muligheder for forebyggelse af arbejdsrelateret stress $i$ vidensarbejdet, Institut for Produktion og Ledelse, Danmarks Tekniske Universitet.
Kristensen, Anders Raastrup (2010): Metaphysical Labour: Flexibility, Performance and Commitment in Work-Life Management, Doctoral School of Organisation and Management Studies PhD Series 2.

Maslach, Christians, Wilmar Schaufeli \& Michael Leiter (2001): Job Bournout, i Annual Review of Psychology, 52, 397-422.

Mishler, Elliot G. (1999): Storylines, London, Harvard University Press.

Pedersen, Anne Reff (2009): Moving Away from Chronological Time: Introducing the Shadows of Time and Chronotopes as New Understandings of 'Narrative Time', i Organization, 16(3), 389-406.

Pedersen, Michael (2008): Tune in, break down, and reboot - new machines for coping with the stress of commitment, i Culture and Organization, 14, 2, 171-185.

Renemark, David (2007): Varför arbetar så få kvinnor med finanser? - en studie av vardagen $i$ finanssektorn, Göteborg, BAS.

Riessman, Catherine Kohler (1993): Narrative Analysis, London, Sage Publications.

Riessman, Catherine Kohler (2008): Narrative Methods for the Human Sciences, London, Sage Publications.

Siegrist, Johannes (1986): Sociological concepts in the etiology of chronic disease: the case of ischemic heart disease, i Social Science \& Medicine, 22, 247-253.

Sørensen, Ole Henning m.fl. (2007): Indflydelse i vidensarbejdet - kan man få for meget af det gode, i Tidsskrift for Arbejdsliv, 9, 2, 3854.

Svenningsen, Stefan \& Mats Alvesson (2003): Managing Managerial Identities: Organiza- 
tional Fragmentation, Discourse and Identity Struggle, i Human Relations, 56, 1163.

Vaare, Eero (2002): On the Discursive Construction of Success/Failure in Narratives of Post-
Merger Integration, i Organization Studies, 23(2), 211-248.

White, Michael (2002): Narrativ teori, København, Hans Reitzel.

Didde Maria Humle er ph.d.-studerende ved Institut for Organisation, CBS.

e-mail:dmh.ioa@cbs.dk

Anne Reff Pedersen er lektor ved Institut for Organisation, CBS.

e-mail: arp.ioa@cbs.dk 